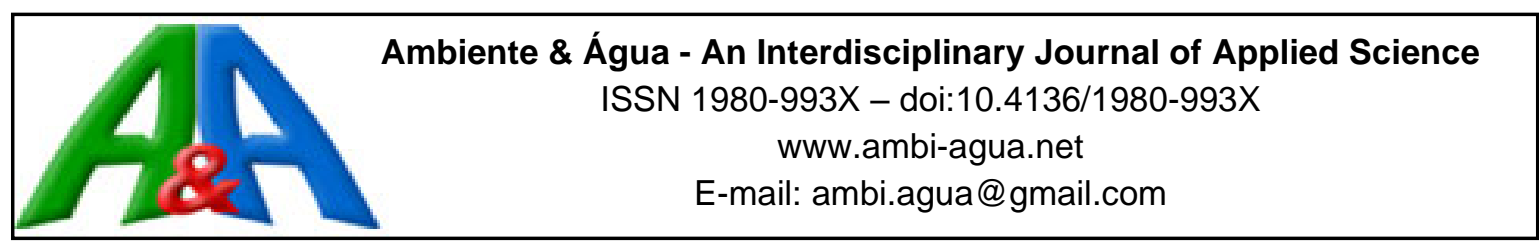

\title{
Micro reservoirs and runoff in the Itaim basin in Taubaté, SP, Brazil
}

\author{
doi: 10.4136/ambi-agua.2333
}

Received: 22 Nov. 2019; Accepted: 27 Dec. 2019

\begin{abstract}
Eduardo Rodrigues dos Santos ${ }^{\text {**; }}$ Marcelo dos Santos Targa'; Paulo Sergio dos Santos ${ }^{1}$; Vicente Rodolfo Santos Cezar ${ }^{1}$; Celso de Souza Catelani ${ }^{2}$

${ }^{1}$ Programa de Pós-Graduação em Ciências Ambientais. Universidade de Taubaté (UNITAU), Rua Visconde do Rio Branco, 210, CEP 12020-240, Taubaté, SP, Brazil. E-mail: targa.marcelo@gmail.com, engpaulosantos18@gmail.com,vrscezar@gmail.com

${ }^{2}$ Instituto de Pesquisas Ambientais em Bacias Hidrográficas (IPABHi), Est. Mun. Dr. José Luiz Cembranelli, 5000, CEP 12081-010, Taubaté, SP, Brazil. E-mail: cscatelani@gmail.com

"Corresponding author. E-mail: eduardomdj@gmail.com
\end{abstract}

\begin{abstract}
Urbanization of the watersheds in developing countries is generally accelerated and disorderly. The urbanization process generates soil impermeability, which impedes the infiltration of rainwater, accelerating surface runoff to favor accumulation of water at the lowest points, causing flooding. The construction of micro reservoirs for rainwater storage and infiltration within residential areas can minimize flood problems. In the present study, the effective precipitation and its reduction in the Itaim stream basin in the city of Taubate, SP, were estimated by usage of 3400 and 6800 liters micro reservoirs to capture water on $125 \mathrm{~m}^{2}$ roofs in different soil occupations, according to the Law 412/2017 of the Master Plan of Municipal Physics of Taubate (PDFMT). Effective precipitation was estimated using the curve number $(\mathrm{CN})$ method, while variation in land use and occupation considered the land area in accordance with current legislation, with urban expansion at 50 and $100 \%$ over the macrozone rural, as well as $100 \%$ urban consolidation. The results showed that surface runoff $(\mathrm{Pe})$ in the Itaim basin increases with the expansion of the urban area, as well as urban consolidation. The use of micro reservoirs considerably reduces runoff volumes. The micro reservoir, with a storage volume of 3400 liters, made it possible to restrict the flow promoted by rain of up to 25 years of return period, simulating the urban expansion of $50 \%$ over the rural area, while the reservoir with 6800 liters in capacity contains rain of up to 200 years return period for the same simulation condition. Although this type of structure was not considered in the municipal land use and occupation law, this study demonstrates that the use of hydraulic systems or elements with potential to reduce runoff can be an important means to ensure the sustainability of urbanization. of watersheds with planned stormwater disposal.
\end{abstract}

Keywords: environmental sciences, land use, sustainability.

\section{Micro reservatórios e escoamento na bacia do Itaim em Taubaté, SP, Brasil}

\section{RESUMO}

A urbanização das bacias hidrográficas dos países em desenvolvimento é geralmente acelerada e desordenada. A urbanização gera impermeabilidade do solo, o que evita a infiltração de água da chuva no solo e acelera o escoamento superficial, favorecendo o acúmulo de água 
nos pontos mais baixos, causando inundações. A construção de micro reservatórios para armazenamento de água da chuva e infiltração em áreas residenciais pode minimizar os problemas de inundação. No presente estudo, a precipitação efetiva e sua redução na bacia do rio Itaim, na cidade de Taubaté, SP, foram estimadas devido ao uso de micro reservatórios de 3400 e 6800 litros para captar água em telhados de $125 \mathrm{~m}^{2} \mathrm{em}$ diferentes usos do solo conforme definição da Lei 412/2017 do Plano Diretor de Física Municipal de Taubaté (PDFMT). A precipitação efetiva foi estimada pelo método do número da curva $(\mathrm{CN})$ e a variação no uso e ocupação da terra considerou a área de terra de acordo com a legislação vigente, com expansão urbana de 50 e $100 \%$ sobre a zona rural da macrozona e consolidação $100 \%$ urbana. Os resultados mostraram que o escoamento superficial $(\mathrm{Pe})$ na bacia do Itaim aumenta com a expansão da área de expansão urbana, bem como com a consolidação urbana. O uso de micro reservatórios reduz consideravelmente os volumes de escoamento. O micro reservatório com um volume de armazenamento de 3400 litros permitiu conter o fluxo promovido pelas chuvas de até 25 anos de retorno, simulando a expansão urbana de 50\% sobre a área rural e os 6800 litros podem conter chuvas de até 200 anos. período de retorno para a mesma condição de simulação. Embora esse tipo de estrutura não tenha sido considerado na lei municipal de uso e ocupação do solo, este estudo demonstra que o uso de sistemas ou elementos hidráulicos com potencial para reduzir o escoamento pode ser um meio importante para garantir a sustentabilidade da urbanização. bacias hidrográficas com disposição planejada de águas pluviais.

Palavras-chave: ciências ambientais, sustentabilidade, uso da terra.

\section{INTRODUCTION}

In urban areas, where impermeable soils predominate, runoff depends on drainage systems, which may not be sufficient and lead to flood and contamination of water bodies in rainy conditions. For continuous rainfall on land covered by vegetation, runoff will occur as there is a saturation of water infiltrated into the soil and surface water is transported to rivers and streams.

The Itaim basin predominantly consists of grasslands, with low and medium infiltration soil. It is located in an area of urban expansion in the municipality of Taubaté. Therefore, it has been under pressure from human occupation (Aguiar et al., 2007) and is in an advanced stage of degradation due to the low level of conservation of soils and roads, extensive cattle raising, erosion and sedimentation of water courses. Approximately $7 \%$ of the basin has exposed soil (Lobato and Targa, 2004).

In the floodplain areas, the soils of the Itaim basin consist of Haplus Gleissolo (Gx) type, while in the lower part, laterally and above the floodplain areas, it is consisted of yellow-red latosol (LVA), at the top and bottom. The intermediate slopes are the yellow-red argisol (PVA) and, finally, closer to the springs, in the upper part of the basin, there is the Haptic Cambisol (Maria Filho et al 2016). These soils have low infiltration capacity when they are completely wet and according to the hydrological classification for soils in Brazil by Sartori, et. al., (2005), are predominantly hydrological soils of type C.

Targa et al (2019) observed that different land and roof uses interfere with infiltration capacity, finding values of basic infiltration rates (VIB) in the Itaim basin, such forest (417 $\left.\mathrm{mm} \cdot \mathrm{h}^{-1}\right)$, Eucalyptus $\left(52 \mathrm{~mm} \cdot \mathrm{h}^{-1}\right)$, pastures $\left(19 \mathrm{~mm} \cdot \mathrm{h}^{-1}\right)$, cultivated areas with corn, rye, sorghum, wheat, etc. $\left(7.2 \mathrm{~mm} \cdot \mathrm{h}^{-1}\right)$ and coffee cultivation $\left(1.5 \mathrm{~mm} \cdot \mathrm{h}^{-1}\right)$, which indicates that the permeability is rapid in the forest, moderate in eucalyptus, slow in pastures and agriculture and still very slow in areas of coffee cultivation, according to the Soil Survey Staff (1993). 
While evaluating the unit's hydrographs in the simulation of runoff in the Itaim stream basin, in a sustainable urbanization scenario for the year of 2020, the basin presented the capacity of flood damping by the vegetation. Points of water infiltration located inside condominiums were projected to work in half of the condominium area (Perim et al., 2015).

Maria Filho et al. (2016) discovered that a 100-year rainfall with a return period would cause water to flow 0.5 m over the Itaim stream bridge on Dr. José Luiz Cembranelli's road and that the use of detention dams could restrict runoff, with a $1.8 \mathrm{~m}$ stretch eliminating flood problems.

Having the land covered by forest enables efficient runoff control, by increasing infiltration. In a water balance monitoring study of the Itaim basin, Targa et al (2019) found only $60 \mathrm{~mm}$ runoff in a tropical forest area, which corresponded to approximately $3 \%$ of rainfall.

Although they are expensive for owners, micro-reservoirs can be useful in order to store water from the roof, avoiding adverse impacts on development, restoring lost natural storage and not transferring the impacts of downstream urbanization.

The present study aimed to estimate the surface runoff in the Itaim stream basin, using the Curve Number Method, considering the land use and occupation, within the geographical limits of the Taubaté Municipal Physics Master Plan - Law 412 / 2017, (PMT, 2019), as well as to verify the reduction in surface runoff by the adoption of micro-reservoirs to capture and store water from the roof.

\section{MATERIAL AND METHODS}

\subsection{Local}

This study was conducted in the Itaim stream basin, located in the municipality of Taubaté, Paraíba Valley, State of São Paulo (Figure 1). The Itaim stream originates at coordinates and S $23^{\circ} 09^{\prime} 46^{\prime \prime}$, and W 45 $36^{\prime} 28^{\prime \prime}$ with its location near the border of Taubaté, with the municipalities of Caçapava and Redenção da Serra and its mouth, in the coordinates W 4530'23" and S 23 01 '28", with much of its area located within the Pilot Farm of the Agricultural Sciences Department of the University of Taubaté.

The climate of the region is of the subtropical-humid type - Cwa (Köppen-Geiger), with an average annual precipitation of $1350 \mathrm{~mm}$, with hot and humid summer, from November to February and cold and dry winter in the months of June to August (Fisch, 1999).

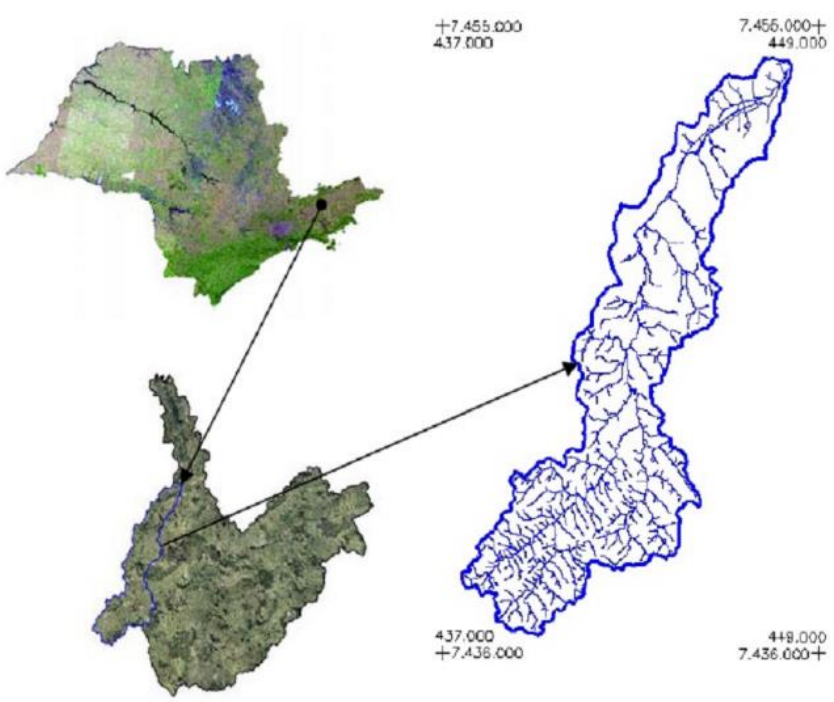

Figure 1. Location of the Itaim basin.

Source: Batista et al., 2005. 
Some morphometric characteristics of the Itaim basin were defined by Targa et al. (2019) and are presented in Table 1.

Table 1. Morphometric characteristics of the Itaim river basin, Taubate, SP.

\begin{tabular}{|c|c|c|c|}
\hline Morphometric & Acronyms & Units & Values \\
\hline Area & A & $\mathrm{km}^{2}$ & 58.9 \\
\hline High altitude & Hmax & $\mathrm{m}$ & 1060 \\
\hline Average altitude & Hmed & $\mathrm{m}$ & 680 \\
\hline Minimum altitude & Hmin & $\mathrm{m}$ & 577 \\
\hline Altitude Amplitude & $\mathrm{Hm}$ & $\mathrm{m}$ & 483 \\
\hline Length of main channel & $\mathrm{L}$ & $\mathrm{km}$ & 21 \\
\hline
\end{tabular}

Source: TARGA et al., 2019.

To estimate surface runoff in the Itaim basin, the Curve Number $(\mathrm{CN})$ method was used based on Equations 1 and 2 (NRCS, 2007).

$$
\begin{aligned}
& P e=\frac{(P-0.2 * S)^{2}}{(P+0,8 * S)} \\
& S=\frac{(25400)}{C N}-254
\end{aligned}
$$

In which:

Pe is the effective precipitation $(\mathrm{mm})$;

$\mathrm{P}$ is the maximum rainfall in a given return period $(\mathrm{mm})$;

$\mathrm{S}$ is the potential infiltration $(\mathrm{mm})$;

$\mathrm{CN}$ is the curve number, without dimensions.

The value of the curve number $(\mathrm{CN})$ can be measured according to the different uses and occupation (coverage) of the Itaim river basin (Targa, 2011) through the Expression 3:

$$
C N_{\text {pond }}=\frac{\sum\left(C N_{C} * A_{C}\right)}{A_{t}}
$$

In which:

CNpond is the measured Value curve, dimensionless number;

$\mathrm{CNc}$ is the value of the curve number for each kind of land use and coverage, without dimensions;

$A_{c}$ is the area of each kind of land use and coverage in ha;

$\mathrm{A}_{\mathrm{t}}$ is the total area of the basin, in ha.

Maximum runoff occurs when the entire basin is contributing to the outflow, so the duration of rain must be equal to the Basin concentration time, which is calculated using the Kirpich Equation 4.

$$
T C=0.57 *\left(\frac{L^{3}}{H}\right)^{0.385}
$$

In which: 
Tc is the concentration time in minutes;

$\mathrm{H}$ is the difference between the furthest spring and the basin outlet in $\mathrm{m}$;

$\mathrm{L}$ is the length of thalweg in $\mathrm{km}$.

Precipitation is one of the main parameters used in the curve number method and, therefore, its definition should be preferably based on local data from intensity-durationfrequency studies. The study for the state of São Paulo, conducted by Martínez Junior and Magni (1999), included the municipality of Taubaté, SP, based on data collected in the years of 1964-65, 1969-88 and 1990-97. However, the authors were able to present an equation consisting of heavy rains (Equation 5) for the duration $t$ in minutes defined in the interval $10 \leq t$ $\leq 1440$ for the season: Taubaté - E2-022, with geographic coordinates Lat. $23^{\circ} 02^{\prime}$ S; Long $45^{\circ} 34^{\prime}$ $\mathrm{W}$ and altitude $610 \mathrm{~m}$.

$$
i, t, T=54.5294(t+30)^{-0.9637}+11.0319(t+20)^{-0.9116}\left(-0.4740-0.8839 \ln \ln \left(\frac{T}{T-1}\right)\right)
$$

In which:

I is the intensity of precipitation in $\mathrm{mm} / \mathrm{min}$;

$\mathrm{t}$ is the duration of the rain in min;

$\mathrm{T}$ is the Return time of precipitation in years.

Based on the map of the established areas in Law 412/2017 of the Master Plan of Municipal Physics of Taubate -PDFMT (PMT, 2019), the perimeter of the Itaim basin was superimposed (Figure 2), establishing the limits and the size of the areas. as shown in Figure 3.

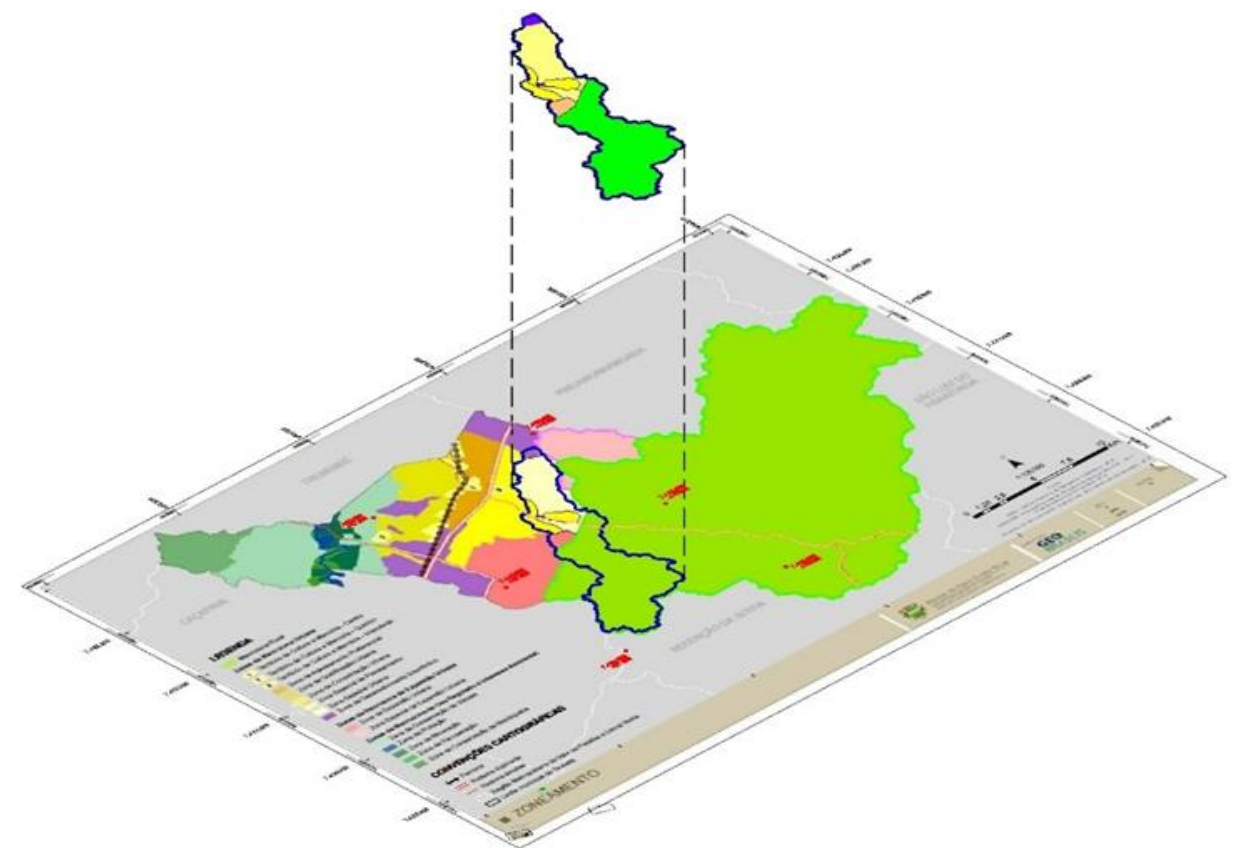

Figure 2. Projection of the Itaim basin on the map of the municipality of Taubaté - Law 412/2017 of the Taubaté Municipal Physics Master Plan PDFMT.

As defined in Law 412/2017 (Master Plan of Municipal Physics of Taubaté - PDFMT), Urban Expansion Zone is intended for lots of up to $500 \mathrm{~m}^{2}$ with up to $65 \%$ impermeability and consists of areas intended housing action and construction of new homes and areas subject to 
land regularization and urban infrastructure. The areas of urban consolidation are destined to lots of less than $500 \mathrm{~m}^{2}$, with a waterproof average of $20 \%$. These are consolidated areas of residence, commerce, services, industries, etc. The Special Urban Zone in general is intended for lots of more than $500 \mathrm{~m}^{2}$, since up to $65 \%$ is possible, it is water resistant and has similar characteristics to the urban expansion area. The Economic Development Zone is basically intended for industrial land and can have up to $72 \%$ waterproof area. Rural Macrozone is specifically destined for the rural environment with conservation activity of forests.

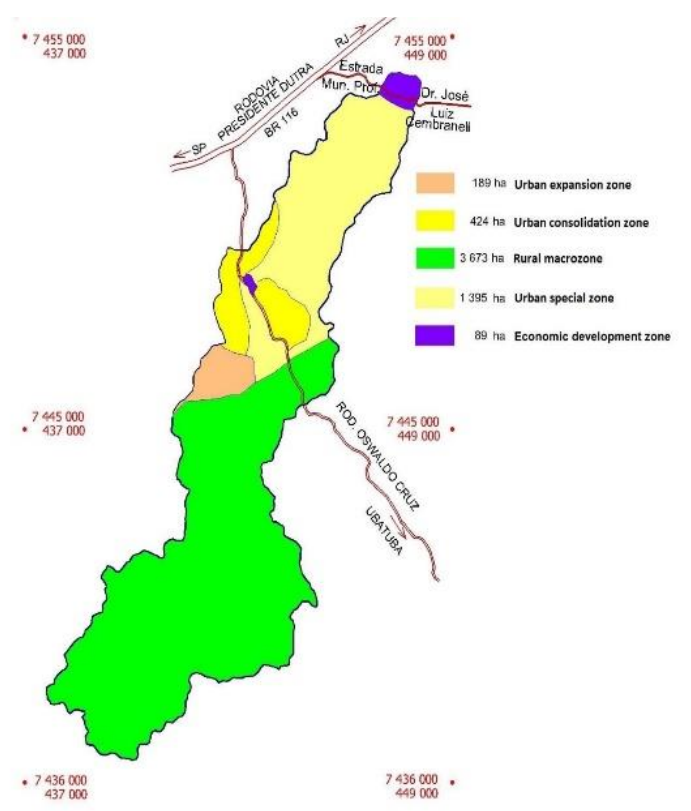

A

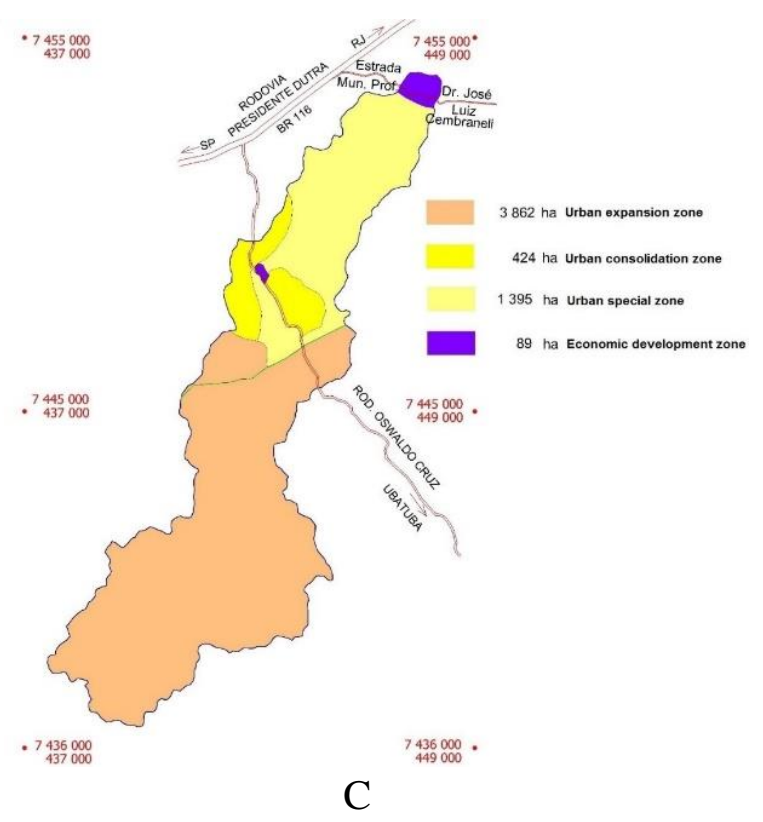

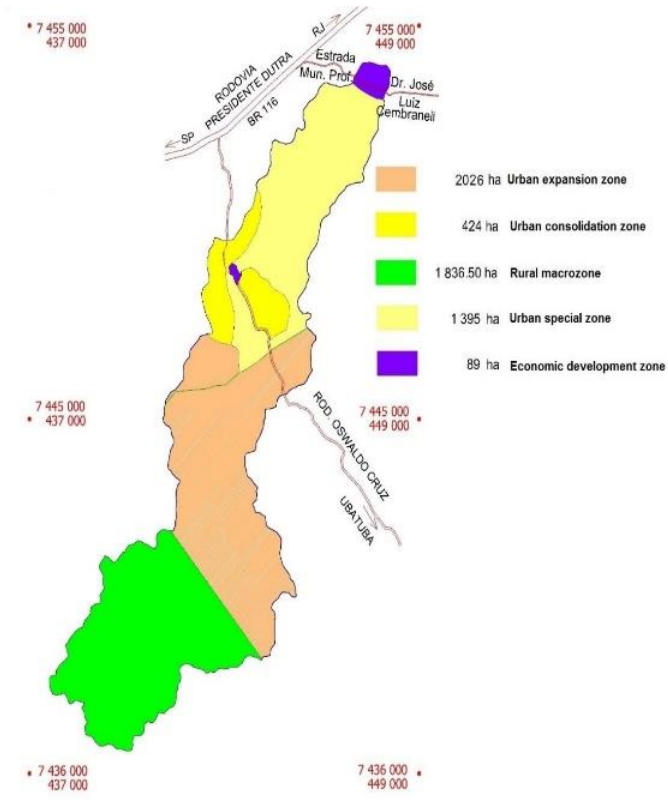

$\mathrm{B}$

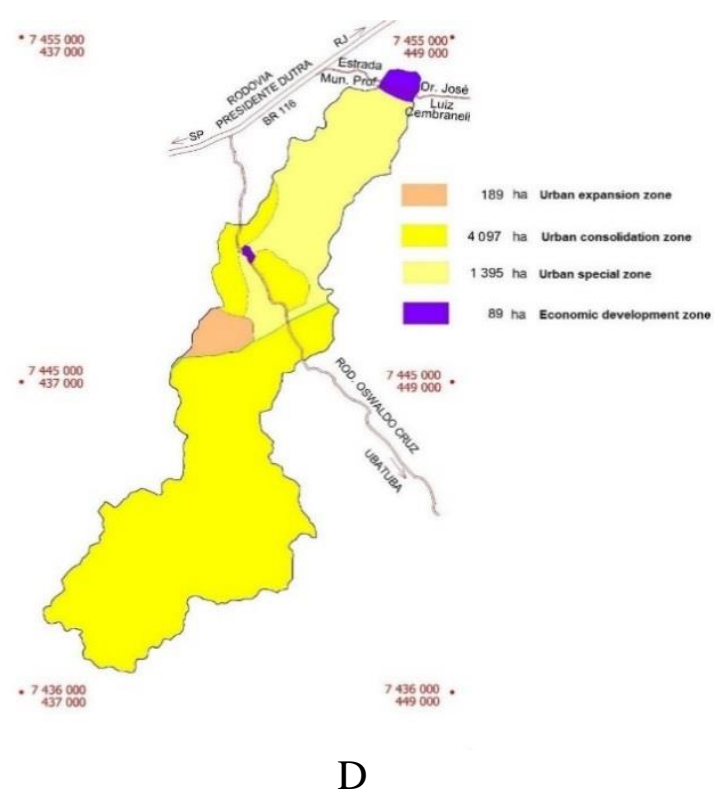

Figure 3. Land use and occupation in the Itaim stream basin in relation to Law 412/2017 - Taubaté Municipal Physics Master Plan - PDFMT (A); Urban expansion over the rural macro area by $50 \%$ (B) and $100 \%$ (C) and urban consolidation (D). 
To verify the effect of use and occupation in the Itaim basin's runoff, simulations were made of changes in the size of urban expansion areas with classes at 50 and $100 \%$ progress on the Rural Macrozone class and finally $100 \%$ of the runoff was carried out. Urban Consolidation Zone Class.

The values of the curve number $(\mathrm{CN})$ for the different land use classes and occupations of the Itaim stream basin were defined based on data from the City of São Paulo city drainage manual (Sao Paulo, 2012) and are shown in Table 2.

Table 2. CN values for the different types of land use and occupation of the Itaim's basin.

\begin{tabular}{|c|c|c|c|c|c|}
\hline Land Use and Occupation Classes & & Area & (ha) & & $\mathbf{C N}$ \\
\hline Urban Expansion Zone - UEZ & 189 & 2026 & 3862 & 189 & 90 \\
\hline Urban Consolidation Zone - UCZ & 424 & 424 & 424 & 4097 & 98 \\
\hline Urban Special Zone - USZ & 1395 & 1395 & 1395 & 1395 & 92 \\
\hline Economic Development Zone - EDZ & 89 & 89 & 89 & 89 & 93 \\
\hline Rural Macrozone - RM & 3673 & 1836.5 & & & 55 \\
\hline $\mathrm{CN}$ pond & 68.84 & 79.98 & 91.12 & 96.21 & \\
\hline
\end{tabular}

\section{RESULTS AND DISCUSSIONS}

The Itaim stream has a steep slope $\left(103 \mathrm{~m} \cdot \mathrm{km}^{-1}\right)$ with a fall of $330 \mathrm{~m}$ in the first $3200 \mathrm{~m}$ and then a smoother slope $\left(4.6 \mathrm{~m} \cdot \mathrm{km}^{-1}\right)$ with a fall of approximately $90 \mathrm{~m}$ in $19500 \mathrm{~m}$, channeling to its exutory on the Una's river (Targa et al., 2019). This characteristic makes the flow quickly reach the flattest areas and cause floods, as Moreira et al (2006) point out; Maria Filho et al, (2016).

Based on the maximum and minimum quota data and the length of the main channel (Table 1), using equation 4 , the concentration time (180 minutes) for the Itaim basin was calculated. When comparing this time with the maximum duration of rain, from the equation 5 (Martinez Junior and Magni, 1999), the maximum rainfall heights $(\mathrm{mm})$ were calculated for the return periods of 2, 5, 10, 15, 20, 25, 50, 100 and 200 years (Table 3).

Table 3. Prediction of maximum rainfall heights $(\mathrm{mm})$ for the Itaim basin in Taubate, SP, based on the return time in years (TR) and the duration of the rain $(t)$ in minutes.

\begin{tabular}{cccccccccc}
\hline Duration $\mathrm{t}$ & \multicolumn{10}{c}{ Return Period - years } \\
\hline (minutes) & 2 & 5 & 10 & 15 & 20 & 25 & 50 & 100 & 200 \\
\hline 180 & 54.4 & 70.3 & 80.8 & 86.7 & 90.9 & 94.1 & 103.9 & 113.7 & 123.5 \\
\hline
\end{tabular}

Based on the maximum rainfall values in Table 3 and the values of measured curve number $\mathrm{CN}$ defined in Table 1, the actual rainfall for different land use classes and occupations of the Itaim river basin was calculated, as defined in Law 412/2017 - Master Plan of Municipal Physics of Taubaté - PDFMT and the simulations proposed in this study.

These results can be seen in Figure 4, where effective runoff originating from rainfall increases depending on the return period and urban expansion by 50 and $100 \%$ over the rural area, as well as consolidation urban due to government regulation in the state of São Paulo, designers use the 100-year recovery period in situations where there is a risk of flooding. Using this return period as an example, the rural Macrozone defined in the Master Plan (Figure 3 A) corresponds to approximately $64 \%$ of the basin area due to a high infiltration potential ( $\mathrm{S}=115$ $\mathrm{mm}$ ) resulting in an effective precipitation of only $40 \mathrm{~mm}$ for the 100 -year recovery period. 
Simulating urban expansion by $50 \%$ over rural areas would already reduce infiltration by $44 \%(\mathrm{~S}=64 \mathrm{~mm})$ and increase effective precipitation by 55\% $(\mathrm{Pe}=62 \mathrm{~mm})$. Similarly, urban expansion in more than $100 \%$ of rural areas would reduce potential infiltration by $78 \%(\mathrm{~S}=25$ $\mathrm{mm}$ ), while effective precipitation would increase $122 \%$ over land use and coverage of the land defined in the municipality's master plan. Taubate $(\mathrm{Pe}=89 \mathrm{~mm})$. These variations occur in urban expansion, where urban devices are not consolidated. The potential infiltration decreases to $10 \mathrm{~mm}$ and the effective rainfall that generates runoff increases to $102 \mathrm{~mm}$ in the simulation of urban consolidation of over $100 \%$ of the rural area.

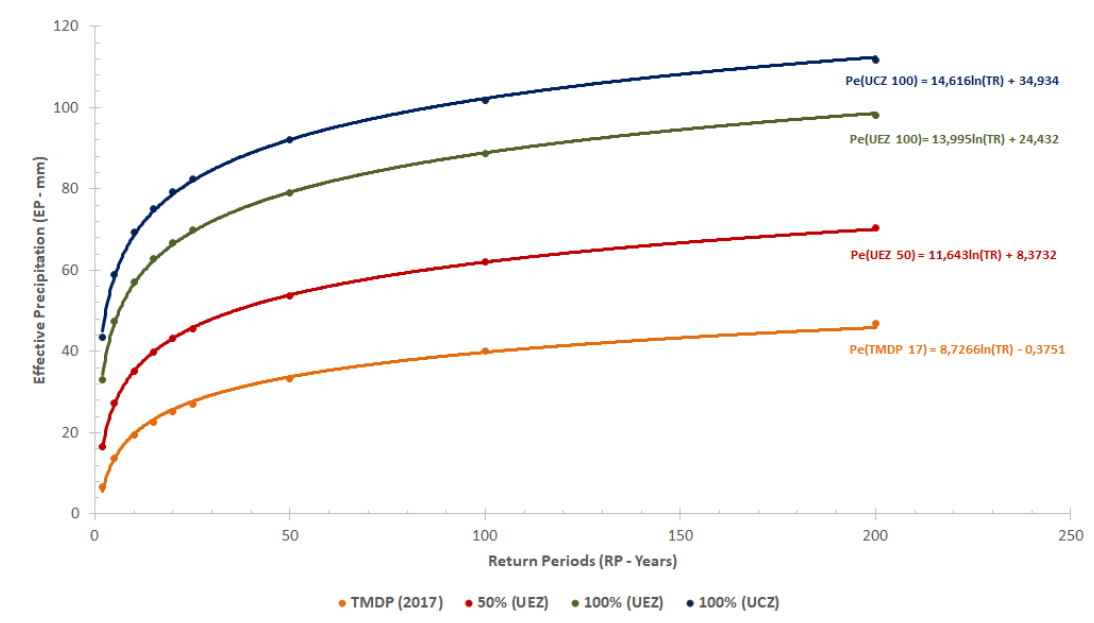

Figure 4. Effective precipitation (Pe) for different kinds of land use and occupation of the Itaim's basin.

The implantation of micro reservoirs with capacity for 3400 liters in the habitable land of the basin by capturing water of a $125 \mathrm{~m}^{2}$ roof can significantly reduce the values of effective precipitation, as can be seen in Figure 5. The straight line marked at zero is the Maximum capacity of the micro tank. On the other hand, it can be inferred that with the land use and occupation defined by PDFMT (PMT, 2017), the maximum rainfall with a return period of less than 25 years would generate less runoff than the capacity of the micro reservoir, which is represented by the negative values in the difference of effective rain and to simulate the use of $50 \%$ of the rural area with urban expansion, this level would be 5 years of return period.

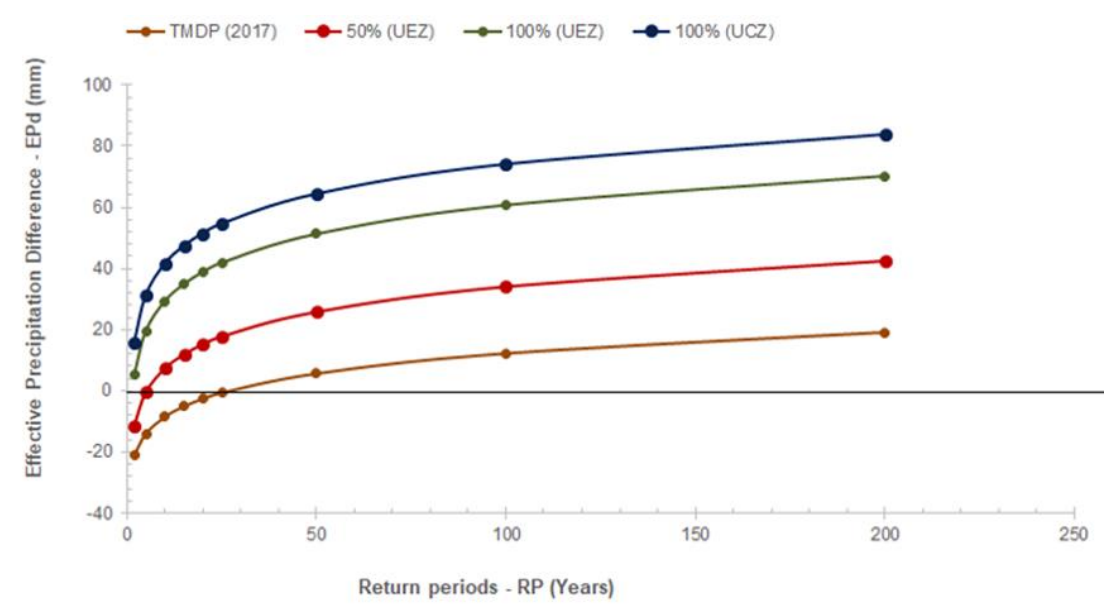

Figure 5. Simulation of effective precipitation (Pe - mm) using a 3400 liter micro tank in the Itaim basin, based on different uses and occupations. 
The effective precipitation for the expected 100-year return period of $40 \mathrm{~mm}$ would be 12 $\mathrm{mm}$; and a $50 \%$ urban expansion would make Pe go from $62 \mathrm{~mm}$ to $34 \mathrm{~mm}$, a $100 \%$ expansion over the rural macrozone would make Pe $(\mathrm{mm})$ go from $89 \mathrm{~mm}$ to $61 \mathrm{~mm}$ and, finally, in urban consolidation, Pe would go from $102 \mathrm{~mm}$ to $74 \mathrm{~mm}$.

The areas studied here are documented in the form of a law, and have not yet been implemented. However, the proposed reduction of runoff from the use of micro reservoirs that capture water from the roof of the houses is very important as it considerably reduces the risks flooding in the lower parts of the basin. Micro reservoirs are simple water storage structures that would be buried in or above the ground. In order to reduce flow, an increase in the reservoir's capacity should be prioritized, while for the double capacity (6800 liters) parameters of land use in certain municipal laws, in 2017, it would not be a choice. Although, as shown in Figure 6, its curve is limited to the maximum capacity of the reservoir. It is also observed that even if urban expansion advances $50 \%$ over the rural area, only maximum rainfall with return periods of more than 50 years would cause runoff.

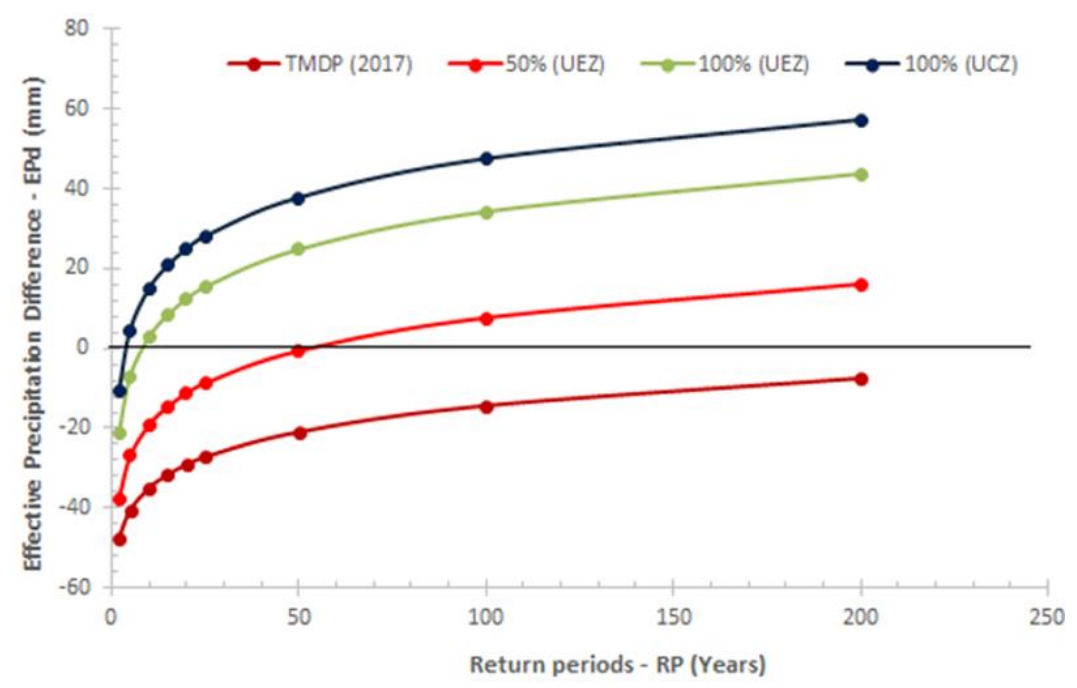

Figure 6. Simulation of effective precipitation $(\mathrm{Pe}-\mathrm{mm})$ with the use of the 6800-liter micro- tank in the Itaim's basin due to different uses and occupations.

As can be seen, the use of reservoirs enables realization that if the Itaim basin develops in terms of urbanization, the rains with a return time of 2, 5 and 10 years of return time would stop at the lot, which is important for the operation of the micro storm drain. However, the costs of establishing this type of retention deposit are the responsibility of the population, since these assets are created in residential lots (Costa Junior et al., 2006). The application of discounts on municipal taxes is an important aspect in persuading the population to construct such retention elements.

\section{CONCLUSION}

The implementation of changes in land use and occupation in the Itaim's basin, as provided in the Master Plan of the Municipality of Taubaté causes a decrease in infiltration rate and increase in runoff.

The use of micro reservoirs in homes with a capacity of 3400 and 6800 liters? considerably reduces runoff in the Itaim's basin, retaining rain with a return period of up to 100 years.

Micro-reservoirs with 3400 liters in capacity are capable of containing rain with a recovery period of up to 25 years, while the ones with 6800 liters would contain 100-year rains. 


\section{REFERENCES}

AGUIAR, L. S. G.; TARGA, M.S.; BATISTA, G. T. Surface runoff in the Itaim Watershed. Revista Ambiente \& Água, v. 2, n. 1, p. 44-56, 2007.

BATISTA, G. T.; TARGA, M. S; CATELANI, C. S.; DIAS, N. W. Modelo de banco de dados ambientais georreferenciados voltado à recuperação e preservação de recursos hídricos de uma bacia de médio porte, o modelo da bacia do Rio Una, Paraíba do Sul, SP (P. 116). In: XVI Simpósio Brasileiro de Recursos Hídricos (XVI SBRH), 2005, João Pessoa. Proceedings[...] Rio de Janeiro: Associação Brasileira de Recursos Hídricos, 2005. v. 1. p. 1-16.

COSTA JUNIOR, L. L. da; BARBASSA, A. P.. Parâmetros de projeto de microrreservatório, de pavimentos permeáveis e de previsão de enchentes urbanas. Eng. Sanit. Ambient., Rio de Janeiro, v. 11, n. 1, p. 46-54, 2006. (http://dx.doi.org/10.1590/S1413).

FISCH, G. F. Distribuição da precipitação em Taubaté (SP). Universidade de Taubaté, Revista Biociências, vol.5, $\mathrm{n}^{\circ}$ 2, 1999.

LOBATO, A. A.; TARGA, M. S. Levantamento do uso e das condições de conservação da água na Bacia hidrográfica do ribeirão Itaim no município de Taubaté- SP. Revista Biociências, v. 4, n. 4, 2004.

MARIA FILHO J; SANTOS, P. S; TARGA, M. S; MOSTARDA NETO, N Barragens de detenção em bacia hidrográfica com uso de curso cata-volume e hidrogramas triangulares sintéticos. Revista Ambiente \& Água, Taubaté, SP, vol. 11 (suplemento), p. 1-17, 2016.

MARTINEZ JUNIOR, F.; MAGNI, N. L. G. Equações de chuvas intensas do Estado de São Paulo. São Paulo: Departamento de Águas e Energia Elétrica; Universidade de São Paulo, 1999. $125 \mathrm{p}$.

MOREIRA, D. W; SANTOS, M. T; BATISTA, G. T. Relações entre chuvas intensas, vazões máximas e sedimentação do ribeirão Itaim, Taubaté, SP. Revista Biociências., Taubaté, v. 12 , n. 1-2, p.44-52, 2006.

NATIONAL RESOURCES CONSERVATION SERVICE. Estimation of direct runoff from storm raifall. In: Hydrology: national engineering handbooks. Washington: USDA, 1997. 79 p. part 630. cap. 10. Disponível em: <www.ftw.nrcs.usda.gov>. Acesso em abril 2007.

PERIM, M. A.; SANTOS, E. R.; LEITE, C. R. S.; GONÇALVES, S. F.; TARGA, M. S. Hidrograma unitário e urbanização em bacia hidrográfica. 2015. p. 1-13. Disponível em: http://www.agro.unitau.br/dspace. Acesso em dez. 2018.

PMT. PLANO DIRETOR FÍSICO DO MUNICÍPIO DE TAUBATÉ - LEI $\begin{array}{lllllll}\text { COMPLEMENTAR } & 412 & \text { DE } & 12 & \text { DE } & \text { JULHO DE }\end{array}$ $<$ https://issuu.com/prefeituradetaubate/docs/pmma_final_2_2_>, Acesso em: 21 jul. 2019.

SÃO PAULO. Secretaria do Governo Municipal de Desenvolvimento Urbano. Manual de Drenagem e manejo de águas pluviais: aspectos técnologicos; fundamentos, V2. SMDU 2012. 220p. Disponível em: https://www.prefeitura.sp.gov.br/cidade/secretarias/ upload/desenvolvimento_urbano/arquivos/manual-drenagem_v2.pdf 
TARGA, M. S. Vazão de projeto em bacias hidrográficas rurais com áreas em declive. 2011. p. 1-20. Disponível em: http://www.agro.unitau.br/dspace. Acesso em: dez. 2016.

TARGA, M. S.; POHL, E.; ALMEIDA, A. A. S. Water balance in soil covered by regenerating rainforest in the Paraíba Valley region, São Paulo, Brazil. Revista Ambiente \& Água An Interdisciplinary Journal of Applied Science, [S.1.], v. 14, n. 6, p. 1-11, 2019. (http://dx.doi.org/10.4136/ambi-agua.2482).

TARGA, M. S.; GONÇALVES, M.C.; CATELANI, C. S.; DIAS, N. W. Human occupation and land use process in the Itaim basin, Taubaté, Brazil. Revista Ambiente \& Água, v. 14, n. 7, p. 1-12, 2019. 